\title{
WHY SUPERMAN WILL NOT SAVE THE WORLD: THEORIZING THE RELATIONSHIP BETWEEN SUFFERING AND DC COMICS SUPERMAN (TRANSLATION INTO RUSSIAN) ${ }^{1}$
}

\section{Kwasu Tembo}

Independent researcher. Harare, Zimbabwe. Email: tembo.kwasu[at]gmail.com

\begin{abstract}
The hypothesis that there is an inextricable link between comic book superheroes and suffering would, to anyone with a cursory knowledge of superhero characters found in DC, Marvel, Image, Wildstorm and other houses, and their histories, ostensibly seem valid. This validity depends on which character one is applying said hypothesis to; the psychological and physical suffering of a Batman being more acceptable as such than that of a Plastic Man, for example. However, using DC Comics character Superman as a case study, this paper explores the inextricable link between Otherness, power, and suffering within the remit of the character's mythos. In order to do so, this paper refers to psychoanalytic concepts elaborated by Sigmund Freud in his text Beyond the Pleasure Principle (1922) as a way of demonstrating that despite the character's conventional appraisal as a positivist humanistic symbol of pure altruism, an insuperable, unimpeachable symbol of selflessness and good morality, there is in fact a fundamental link between Superman's 'tridentity' of selves (Clark Kent/Kal-El/Superman), the character's own suffering, and human suffering on a terrestrial scale, as represented within the numerous realities of the DC Comics Multiverse.
\end{abstract}

Keywords

pain; suffering; power; otherness; Superman; Waid; Freud; pleasure-principle

This work is licensed under a Creative Commons «Attribution» 4.0 International License

1 The editors are grateful to the author for permission to translate and publish the article (Tembo, K. (2020). Why Superman Will Not Save the World: Theorizing the Relationship Between Suffering and DC Comics Superman. Galactica Media: Journal of Media Studies, 2(3), 119-137. https://doi.org/10.46539/gmd.v2i3.114) 


\section{ПОЧЕМУ СУПЕРМЕН НЕ СПАСЕТ МИР: ОСМЫСЛИВАЯ СВЯЗЬ МЕЖДУ СТРАДАНИЕМ И СУПЕРМЕНОМ ИЗ DС СОМІСS (ПЕРЕВОД НА РУССКИЙ ЯЗЫК) ${ }^{1}$}

\section{Тембо Квасу}

Независимый исследователь. Хараре, Зимбабве. Email: tembo.kwasu[at]gmail.com

\section{Аннотация}

Гипотеза о том, что существует неразрывная связь между супергероями комиксов и страданиями, покажется верной любому, кто хоть как-то знаком с супергероями DC, Marvel, Image, Wildstorm и их историями. Но правдивость этого утверждения зависит от того, к какому персонажу применена указанная гипотеза. Например, психологические и физические страдания Бэтмена больше подходят под эту гипотезу, чем страдания Пластичного Человека. Используя в качестве примера персонажа DC Comics Супермена, данная работа исследует неразрывную связь между Инаковостью, властью и страданиями в рамках мифологии персонажа. Для реализации подобного исследования, автор опирается на психоаналитические концепции, изложенные Зигмундом Фрейдом в его работе «По ту сторону принципа удовольствия» (1922 г.), чтобы показать, что, несмотря на традиционную оценку персонажа как гуманистического символа чистого альтруизма, непобедимого, безупречного символа самоотверженности и морали, на самом деле существует фундаментальная связь между «троичностью» Супермена (Кларк Кент / Кал-Эл / Супермен), страданиями персонажа, и человеческими страданиями в земном масштабе. Это представлено в многочисленных мультиверсиях мультивселенной комиксов DC.

\section{Ключевые слова}

боль; страдание; власть; инаковость; Супермен; Уэйд; Фрейд; принцип удовольствия

\section{(c) (1)}

Это произведение доступно по лицензии Creative Commons «Attribution» («Атрибуция») 4.0 Всемирная

1 Редакция благодарит автора за разрешение на перевод и публикацию статьи Tembo, K. (2020). Why Superman Will Not Save the World: Theorizing the Relationship Between Suffering and DC Comics Superman. Galactica Media: Journal of Media Studies, 2(3), 119-137. https://doi.org/10.46539/gmd.v2i3.114 


\section{I. ВВЕДЕНИЕ: СУПЕРМЕН И СТРАДАНИЕ}

Существует множество способов описать «страдание». Оно может относиться к физической и/или душевной боли, или - в более широком смысле - к любым неприятным ощущениям и/или эмоциям. Соответственно, предположение о неразрывной связи между образом Супермена и мотивом страдания может показаться несовместимым с, пожалуй, самым узнаваемым постиндустриальным попкультурным образом гипермаскулинной андроцентричной силы. Хотя супергерои не всегда идентифицируются через страдание или определяются им, в данной работе утверждается, что оно является неотъемлемым элементом повествования и тематического портрета персонажа, а также отправной точкой всей мифологии Супермена.

Как будет показано, последствия страданий супермена важны, потому что они ставят под сомнение историко-культурную ценность персонажа как иконы героического альтруизма. Как такое физически почти неуязвимое существо, как Супермен, не просто постоянно сталкивается со страданиями и болью других, но и сам испытывает боль или страдает? Мое понимание «страдания» применительно к Супермену связано с этимологией английского слова «suffer», образованного от двух латинских слов sub- «под, ниже» и ferre - «носить», образуя буквально «носить под чем-либо». Другое латинское значение, полученное из сочетания слов «sub» и «ferre», передает психологический смысл страдания, который я и буду исследовать в этой работе. Эти два слова также могут означать «брать на себя». Под страданием, следовательно, я имею в виду сочетание психологических и эмоциональных неврозов, которые формируют основной комплекс персонажа, основанный на онто-экзистенциальном различии, или Инаковости, которую персонаж всегда несет, в прямом и переносном смысле, в человеческом обличии Кларка Кента, и потребности в принадлежности, которую оно принимает на себя в роли Супермена.

Хотя большинству читателей привычно обращение «он» (he) по отношению к Супермену, типичное как для его создателя Джерри Сигела, так и для современных авторов, я должен кратко пояснить, почему предпочитаю использовать в данной работе местоимение «оно» (it). Действительно, это может показаться отвлекающим или парадоксальным. Однако я исхожу из того, что Супермен - это, прежде всего, инопланетянин, внеземное существо, обладающее многими внешне идентичными с человеком чертами, которые, как бы убедительны они ни были, не должны умалять факт существенного его отличия от чело- 
века. Более того, обращение «он», если рассуждать логически, в полной мере относится лишь к одной трети всех личностей, которые «носит» Супермен / Кал-Эл, а именно к Кларку Кенту. Мое намерение использовать для обсуждения Супермена местоимение «оно» отчасти объясняется тем, что этика, лежащая в основе этой статьи, является ксенологической. Если, например, я хочу основываться на ксенологическом подходе Фредрика Джеймсона к прочтению текстов с инопланетными существами, который он развивает в книге «Археология будущего: утопия и иные научные вымыслы» (2007), то использование слова «оно» важно, поскольку подчеркивает тот факт, что Супермен - инопланетянин. Независимо от методологического подхода, который можно применить к анализу персонажа, без учета того, насколько он сложен или проработан, это не изменит того факта, что, говоря диегетически, герой является пришельцем. Сочетание этого факта и моего желания сохранить некоторую чуткость к ксенологическим характеристикам Инаковости требует стратегии, которая не игнорирует онто-экзистенциальные сложности персонажа, просто называя инопланетное существо «он», потому что оно выглядит как сильный человек мужского пола. Это было бы неверным сохранением антропоцентрической привилегии, привилегии, к альтернативе которой стремится центральная гипотеза. Я не считаю, что использование местоимения «оно» для обращения к Супермену объективирует персонаж. Напротив, утверждаю, что это подчёркивает: персонаж представляет собой интересную альтернативу любой диалектике человек/нечеловек именно потому, что супермен объединяется обе категории, что добавляет ценность человеческой сопричастности к инопланетному сироте, а также определяет философские и психоаналитические последствия этого.

Основная цель данной работы - осмысление феномена страдания в связи с образом Супермена. Методологической основой послужила дискуссия Зигмунда Фрейда о взаимоотношениях между страданием, удовольствием и болью (работа «По ту сторону принципа удовольствия», 1922). Признаю тот факт, что обращение к Фрейду в этом качестве может повлечь за собой возвращение фигуры Супермена в мессианские дискурсы, чего стремлюсь избежать. Данная работа менее ориентирована на прочтение боли Супермена как некоего образа плачущего бога. Скорее, эта статья посвящена исследованию проблемы боли Супермена в контексте вопроса о границах опыта радикального Чужого, живущего среди людей. В качестве дополнительного концептуального инструментария в статье используется теория о психофизическом феномене алголагнии, когда тело получает удовольствие от боли, как способе анализа обратной логики, действующей между удоволь- 


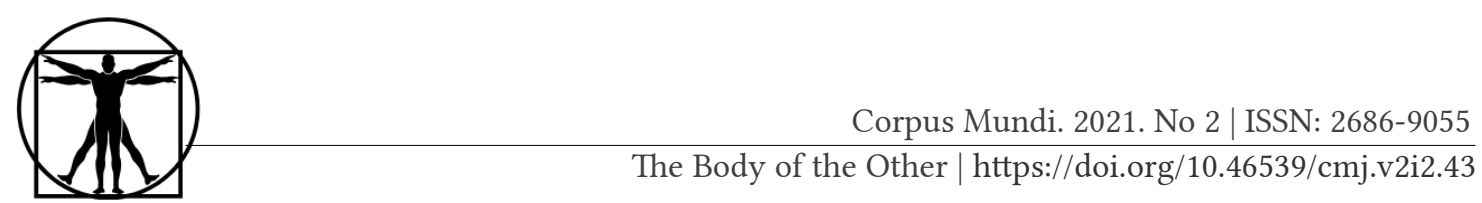

ствием, желанием, болью и страданием в специфически героической мифологии персонажа. Проводя психоаналитическое прочтение мотива страдания Супермена, данная статья ставит своей целью отход от редукционизма мессианских интерпретаций. Обращаясь к одной из самых влиятельных трактовок природы страдания Супермена в современных комиксах, я стремлюсь соединить взгляды Марка Уэйда с психоаналитическими концепциями, чтобы раскрыть и исследовать богатые психоэмоциональные, философские и социально-политические последствия рассматриваемого феномена.

\section{II. НЕИЗМЕННОЕ, ТЕМНОЕ И СКРЫТОЕ: ПСИХОАНАЛИТИЧЕСКОЕ ПРОЧТЕНИЕ ПРИРОДЫ СТРАДАНИЙ СУПЕРМЕНА}

Данное исследование должно восприниматься в общем ряду всех других научных и художественных работ, стремящихся представить Супермена и подобных ему персонажей вне рамок ограниченного мессианского подхода. В работе признается, что использование теории Фрейда может вернуть нас к фигуре мессии, поскольку, например, тотемическая орда и жертвоприношение Первоотца представляют собой корни религии. Эта тема, в той или иной степени рассматриваются многими учеными, в частности в работах Питера Кугана «Супергерой: тайное происхождение жанра» (2006), Кристофера Ноулза «Наши боги носят спандекс» (2007) и Гранта Моррисона «Супербоги: наш мир в эпоху супергероев» (2012), которые утверждают, что слияние таких понятий, как власть, радикальная Инаковость и якобы альтруистическое и морально / этически гуманитарное использование этих сил неизбежно несет в себе мессианский подтекст. В противовес этому, в данной статье представлено более нюансированное психоаналитическое осмысление того, что значит страдание для такого существа, как Супермен. Развиваемое в этом анализе прочтение является не столько рефлексией идей, приравнивающих Супермена к фигуре мессии, сколько того, что ядро всех страданий персонажа кроется в конфликте между сверхъестественной силой и Инаковостью и нуминозным притяжением комплекса принадлежности.

Для начала рассмотрим одну из возможных мессианских ассоциаций, возникающих при анализе образа Супермена в контексте фрейдистских идей. Эссе Фрейда «Тотем и табу» (1919), в котором исследуется первобытная орда и жертвоприношение первобытного отца как зачатки религии и, следовательно, мифа о мессии, делает эту связь очевидной в рамках аналитической концепции страдания. В некотором 
смысле Супермен может выступать для многих читателей как тотем страдания: существо, которое испытывает муки ради тех, кто менее силен. Согласно Фрейду, тотемический отец

\begin{abstract}
используется в попытке загладить жгучее чувство вины и добиться своего рода примирения с отцом. Тотемическая система была своего рода соглашением с отцом, при котором последний давал все, что фантазия ребенка могла ожидать от него, защиту, заботу и терпение, в обмен на что было обещание чтить его жизнь, то есть не повторять против тотема действий, из-за которых погиб реальный отец (Freud, 1919, p. 213).
\end{abstract}

Супермен традиционно воспринимается как функционирующий подобно тотемическому суррогатному отцу - символу терпения, справедливости, правды и альтруизма. Самый традиционный попкультурный образ Супермена - это неуязвимое существо с несокрушимым чувством морального долга, отдающее свои колоссальные силы и неутомимый дух на защиту угнетенных и борьбу с несправедливостью вопреки «незыблемым законам» конституции Соединенных Штатов Америки. Подобно религиозному тотемизму, который вуалирует подлинную жестокость жертвоприношения, убийства и поедания первобытного отца, лежащих в основе религиозной системы, символическая сверхсубъективная позиция Супермена, обладающего совершенной моралью, и его скрытое тотемическое значение помогают «затушевать реальное положение вещей и [...] заставляют забыть» о сложности сочетания неуязвимости, силы и субъективной и действительно уникальной моральности, которую герой одновременно воплощает и проблематизирует (Freud, 1919, р. 213). В этом смысле то, что человеческая вера мультиверса DC в Супермена как в символ двух центральных идеалов современной западной цивилизации - «истины» и «справедливости», делает их спасителя, как и общество, которое он защищает, построенным и поддерживаемым благодаря общему соучастию в чувстве вины персонажа, стремящегося к принадлежности, а не к истинной справедливости. В процессе дальнейшей аргументации центральным будет утверждение, что так называемые добрые дела Супермена могут быть описаны как мораль, «основанная частично на нуждах общества и частично на искуплении, которого требует это чувство вины» (Freud, 1919, р. 213).

Полагаю, что то, как человек воспринимает страдания Супермена, показывает его/ее понимание природы персонажа; то есть, воспринимается ли Супермен больше символом, чем личностью, или наоборот. Для того, чтобы термин «супергерой» был применим к Супермену, персонаж должен либо страдать (будь то кровавые побои в драке с Лобо или Дарксайдом, истощение от красного солнца или криптонита, или, 


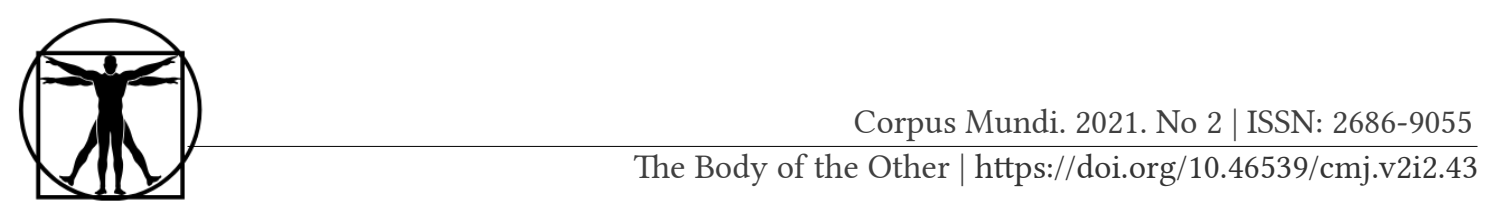

например, магические раны), либо в какой-то форме участвовать в страдании, сопереживать и спасать на многих землях мультивселенной DC. Эти страдания за правое дело, за невинных, за угнетенных являются частью мифологии Супермена. Как персонаж справится с этим? Стоически принимая страдания и ужас происходящего? Отстраненность, облеченная в повышенную объективность, которой может быть наделен физически необычный инопланетянин, живущий среди человечества? Если это так, то подспудно предполагается, что страдания, как психологические, так и физиологические, - это явления, присущие исключительно человеку. И хотя внешне Супермен кажется крепким мужчиной, он является пришельцем с вымышленной планеты Криптон, уничтоженной в результате апокалиптического геологического катаклизма. Во многих мирах мультивселенной DC криптонцы обладают удивительными способностями в результате воздействия желтого солнца, вокруг которого обычно вращаются эти планеты. Среди них - сверхскорость, сверхобоняние, рентгеновское зрение, способность летать, физическая неуязвимость и наличие супермозга. Однако, после разрушения Криптона в этом наборе характеристик не хватает культурного референта, народа, языка, истории и, следовательно, чувства принадлежности. Благодушный псевдо-мессианский образ Супермена как почти всемогущего оптимиста, трудолюбивого гуманиста и могущественного филантропа действительно предполагает, что герой относится к страданиям стоически, хотя и позитивно. Это не отменяет психологических и эмоциональных страданий, испытываемых героем в культурных и социально-политических условиях, в которых действуют супергерои. Кто-то может поспорить, что страдания и смерть являются основными человеческими проблемами, а Супермен - почти неуязвимый инопланетянин, поэтому он не может страдать подобно людям, это не означает, что криптонец не может страдать in principium.

Эта проблема получила свое наиболее выраженное развитие в супергеройских комиксах DC 1980-х гг. В этот период персонаж страдал, переживал и преодолевал личную трагедию, связанную не только с потерей Кары Зор-Эл/Супергерл, своей «кузины», во время основного сюжетного цикла «Кризис на бесконечных Землях» (1986), но и со смертью Джонатана Кента, суррогатного / приемного / земного отца персонажа в «Последние дни мамы и папы Кента» в Superman Vol. 1, № 161 (1963) и «Конец» в Superman Vol. 2, № 77 (1993). В каждом случае персонаж сталкивался с бездной нигилизма и впоследствии преодолевал ее. Алан Мур и Дэйв Гиббонс, однако, применили явно психологический подход к проблеме страданий Супермена. В сентябре 1985 года в ежегоднике «Superman» № 11 была опубликована история 
под названием «Для человека, у которого есть все». В ней Чудоженщина, Бэтмен и Робин отправляются в Крепость Одиночества Супермена, чтобы отпраздновать его день рождения. По прибытии они обнаруживают своего коллегу в кататоническом состоянии с огромной инопланетной растительной формой жизни, прикрепленной к его груди. Растение, называемое Черным милосердием, встраивается в своего хозяина/жертву в форме симбиота. Оно питается его «биоаурой», одновременно получая доступ к ее бессознательному разуму, что позволяет создавать логическую симуляцию «счастливого конца», о котором больше всего мечтает жертва, и что позволяет растению держать ее в повиновении. Изначально «счастливый конец», который представляет себе Супермен, - это симуляция того, какой была бы жизнь героя, если бы Криптон не был уничтожен. В этой фантазии Супермен счастливо женат на бывшей криптонской актрисе Лайле Леррол, он - успешный археолог и отец двоих детей.

Пока Супермен находится под властью симуляции Черного Милосердия, Чудо-женщина сражается со злым космическим тираном Монгулом, ответственным за случившееся с Суперменом. Одновременно Бэтмен и Робин пытаются освободить разум Супермена от контроля растения. К счастью иллюзия, которую Черное Милосердие создает для Супермена, не идеальна. По мере того как его воля борется с контролем растения, «счастливый конец» становится все более ужасным. Выясняется, что престарелый отец Супермена Джор-Эл был уволен из Научного совета Криптона после того, как его теория уничтожения планеты была опровергнута. В результате этого Джор-Эл стал озлобленным членом жестокой и экстремистской реакционной религиозной фракции под названием «Меч Рао», чья этика включает в себя крестовый поход против современного техноцентричного криптонского общества. В итоге Супермен освобождается от власти Черного Милосердия. Мур и Гиббонс показывают читателю редко изображаемого яростного и смертоносного Супермена: разъяренного, растерянного и с разбитым сердцем. После напряженной схватки Робин спасает положение, бросая Черное милосердие в Монгула, заставляя межзвездного военачальника мучиться в собственной ловушке. Можно сделать вывод, что самая сильная форма страданий Супермена результат не применения против него физической силы или, как в случае с криптонитом, или бессилия. Мур показывает, что именно психологическая травма, связанная с предоставлением персонажу реальной или виртуальной возможности выбора быть другим, быть «нормальным», быть полностью человеком, слишком человеком, а затем последующим лишением этой возможности или, что еще хуже, 
демонстрацией того, что она всегда была ложной, является источником самого настоящего и глубокого страдания Супермена (Weldon, pp. 215-216).

\section{III. СПАСЕННЫЕ ОТ СТРАДАНИЙ ЧЕМПИОНОМ СТРАДАНИЯ: СУПЕРМЕН, БОЛЬ, ВЛАСТЬ И СТРАДАНИЯ}

В книге «Настоящая правда о Супермене, а также обо всех нас» (2005) Марк Уэйд описывает Супермена как культурный институт, почти повсеместно известный не только как провозвестник современных супергероев, но как символ «нескончаемой битвы» за правду и справедливость. Таким образом, Уэйд рассматривает Супермена как наиболее близкий «современной западной культуре образ ${ }^{1}$, который является воплощением бескорыстия. [Как следствие], самое верное моральное утверждение, которое можно сделать о Супермене, заключается в том, что он неизменно ставит нужды других на первое место» (Waid, p. 3). Описание Уэйда предполагает, что сила персонажа фундаментально опосредована моральным и, в частности, альтруистическим этосом персонажа. Аналогичным образом в разделе «Что такое супергерой?» Фингерот доходит до предположения, что Супермен, как и различные супергерои комиксов - в качестве примера он приводит Тора и Бэтмена, - являются воплощением одной и той же фундаментальной моральной этики (Fingeroth, pp. 16-17).

Однако в книге «Супергерои: современная мифология» (1992) Ричард Рейнольдс отмечает, что Супермен, так же как любой другой сверхсильный персонаж, решивший придерживаться так называемой морально праведной или просоциальной позиции, «по большому счету не является блюстителем буквы закона; он не являются стражем порядка, нанятым государством» (Reynolds, p. 74). Этот факт делает карательное использование силы Суперменом несколько парадоксальным не только с точки зрения юридической несостоятельности. Кажется странным, что существо, обладающее силой и Инаковостью, решило бы поставить свою силу в зависимость от какого-либо идеала, который запрещает полное выражение этой силы и/или Инаковости. На мой взгляд, консервативная гражданская позиция мейнстримных супергероев комиксов, вроде Супермена, является прямым следствием интерпелляции сверхспособностей в политику. Под термином «интерпелляция» я подразумеваю процесс, в ходе которого индивиды причис-

1 Автор прибегает к использованию термина “Champion" - отсюда вытекает и название раздела. К сожалению, адекватно перевести на русский данное выражение невозможно, поэтому переводчик оставляет за собой право использовать нейтральное «образ» 
ляются и становятся субъектами идеологических рамок, опосредующих их опыт субъектности, а также субъектности других. В результате разрушительность силы Супермена и его Инаковость оказались погребенными в различных политических взглядах и идеалах читателей, перенесенных со временем в вымышленные миры мультивселенной DC.

В книге «Супергерой: Тайное происхождение жанра» (2006) Питер Куган дает почти такое же определение супергероя, как и Фингерот, утверждая, что супергерой - это «героический персонаж с бескорыстной, просоциальной миссией» (Coogan, p. 30). Об этом свидетельствует и определение супергероя, данное Джефом Лоэбом и Томом Моррисом в книге «Супергерои и философия: истина, справедливость и сократический путь» (2004), авторы описывают Супермена как пример подлинно альтруистического Пути. Это определение демонстрирует читателям, что «супергерои работают не только для людей, которые ценят их усилия, но часто и для людей, которые критикуют и поносят их. Они делают то, что делают, не потому, что это популярно. Они делают это потому, что это правильно» (Loeb \& Morris, p. 28, курсив автора статьи). Можно увидеть редуктивное, прямо или косвенно, слияние понятий суперсилы, этических воззрений альтруизма и просоциальных планов - в том виде, который соответствует требованиям морального совершенства, присущим узкой гуманистической концептуализации термина «герой».

Независимо от того, насколько тематически и эстетически нюансированными могут быть такие тексты, как «Возвращение Тёмного Рыцаря» (1986), «Хранители» (1986) или «Чудо-человек» (1985), с точки зрения оценки напряжённости, присущей вышеупомянутым представлениям, они были редкими случаями до конца 1980-х гг. Нарративы, подобные текстам Мура и Миллера, в которых радикальные последствия отношений между властью, утопией и антиутопией доводятся до радикальных результатов (у Доктора Манхэттена, Чудо-человека или самого Супермена), на протяжении большей части современной истории комиксов, как правило, рассматривались лишь частично или вообще не упоминались в рамках морально-эссенциалистского понимания подобных сверхсуществ. Этот подход стал ведущей традицией изображения мейнстримных героев.

Нельзя правильно рассмотреть вопрос о страданиях неуязвимого существа без анализа того, почему оно делает то, что делает, не изучив желания Супермена. Что может предложить человеческая социальнополитическая и культурная реальность, в которой «безудержный капитализм всегда побеждает, где политики всегда лгут, где спортивные кумиры принимают наркотики и бьют своих жен и где белые заборы 


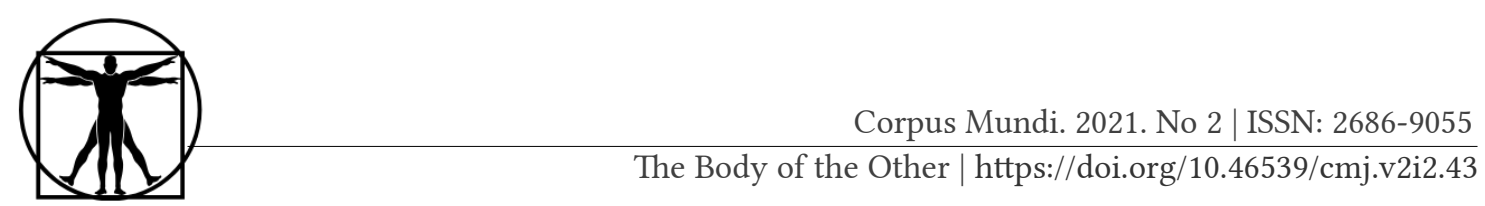

подозрительны, потому что скрывают темные вещи», такому существу, как Супермен? (Waid, p. 6). В книге Пола Дини и Алекса Росса «Супермен: мир на Земле» (1999) читателя убеждают, что Супермен больше всего хочет стать общественно-политическим и культурным катализатором, не мессианским идолом, а моральным образцом, который подстегнет человечество к переоценке различных идеологий и тем самым преобразованию их на благо всего вида. После того, как Супермен помогает в проведении рождественских праздников в Метрополисе, он встречает молодую женщину, страдающую от голода. Это вдохновляет Супермена на исследование проблемы голода в мире. Прежде чем герой начинает использовать свою сверхъестественную физическую силу, политическое влияние и культовую известность для решения этой давней проблемы человеческого бытия, он размышляет:

\begin{abstract}
Я вспомнил своего отца. Будучи фермером, он обладал естественным пониманием Земли. Я помню, как он говорил мне, что этот мир способен прокормить всех своих обитателей. Даже сейчас, когда людей так много, еды предостаточно для всех. «Проблема..., как имел обыкновение говорить папа, - люди..., сколько мы ни живем, у нас всегда были сложности с тем, чтобы делиться. Кажется, все слишком активно держатся за то, что у них есть, чтобы озаботиться тем, как живут их соседи». Папа сказал, что нужен особенный человек без личной корысти, чтобы все поняли, что может предложить мир. Кто-то, кто мог бы отложить свои собственные нужды в сторону, чтобы помочь общему благу. Я не претендую на то, чтобы считать себя таким человеком, хотя я всегда старался быть рядом с другими. Рассматривать свои способности как дар, причем не мне одному, а всем, кто в них нуждается. За эти годы я помог стольким людям, скольким смог. Не мне диктовать человечеству правила. Но, возможно, вид того, как я борюсь с голодом в глобальном масштабе, вдохновит других на собственные действия. Это, безусловно, пример, который стоит показать» (Dini and Ross n.p.).
\end{abstract}

Каким бы благородным или наивным ни казался этот симптоматичный пример утопического видения потенциала человечества в процитированном и множестве других комиксов, гуманизм Супермена не лишен определенных сложностей. Учитывая сверхчувствительность героя, равнозначную крайней наблюдательности, невозможно поверить, что персонаж не будет постоянно подвергаться воздействию ужасов человеческого бытия на Земле. Более того, Супермен не только сталкивается с этими ужасами, но и активно ищет их. Будучи в образе Кларка Кента представителем медийных институтов государства, герой постоянно следит и ежедневно сообщает о насилии, эксплуатации, предрассудках, коррупции и экологической нечистоплотности человечества. Принимая во внимание вышеупомянутые положительные оценки персонажа, вопрос здесь в первую очередь заключается 
в ценности Супермена как особого примера на фоне продолжающихся страданий человеческой расы.

Если верить общепринятой оценке персонажа, и если ни материальные блага, ни имущество, ни слава, ни лавры какого-либо рода не являются мотивом действий Супермена, то что может предложить Супермену диегетическая Земля и ее человечество, которое скорее всего кажутся пришельцу последовательно следующим по пути собственного самоуничтожения? Ответ, который предлагает Уэйд, основан на сверхвозможностях Супермена и, как следствие, солипсическом чувстве крайней изоляции. Физическая и эмпирическая неуязвимость силы и сверхъестественной Инаковости со стороны персонажа порождают состояние крайнего смещения, постоянного разлома и устойчивого экзистенциального кризиса самоосознания. Решением этих неискоренимых страданий, которые персонаж всегда испытывает, находясь на Земле, является, по мнению Уэйда, чувство принадлежности. Но, на мой взгляд, принадлежность не так легко достижима, и, может быть, вовсе невозможна для такого существа, как Супермен, на Земле, напоминающей социополитическую, экономическую и культурную реальность читателя. На этой Земле вопрос принадлежности для Супермена всегда сводится к готовности страдать, подавляя фундаментальные основы своего бытия, а именно - свою силу и Инаковость.

Согласно общепринятому пониманию Супермена, персонаж больше всего нуждается:

1) в «Истине», «Справедливости» и мире для всего человечества;

2) в Лоис Лейн;

3) в принадлежности.

Уэйд предполагает, что, помимо мечты героя быть ярким примером потенциала утопического Завтра для Земли и всей жизни на ней, или даже возможности быть всецело с Лоис без извечной помехи в виде его суперсилы (Супермен) и Инаковости (Кал-Эл), именно третий аспект устремлений героя является самым желанным. Отбросив проблемы, присущие приравниванию человеческой психологии внеземному поведению, Уэйд ссылается на работу Абрахама Маслоу «Теория человеческой мотивации» (1943), утверждая, что в иерархии потребностей именно психологическое стремление принадлежать является наиболее сильной у человека и располагается следом за различными физиологическими потребностями, начинающимися с питания: 


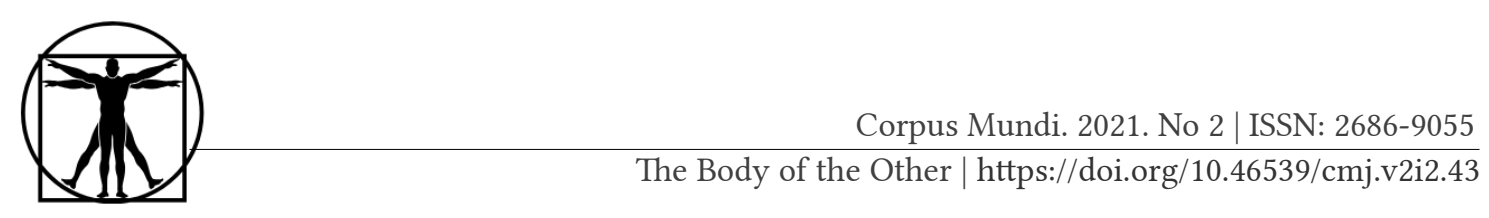

Голод, базовая потребность для выживания, может рассматриваться как изначальное состояние человеческого существа. Это потребность, которая возникает всегда и может быть отсрочена лишь на мгновение, несмотря на количество или качество пищи. В «Мире на Земле» Супермен отказывается от празднования Рождества, проводимого в «Дейли Плэнет». Вместо этого он исследует в архивах редакции проблему голода в мире, его причины, последствия и возможные решения. Интересно, что, рассматривая жуткие фотографии недоедающих, голодающих детей и других жертв голода, Супермен размышляет: «Какая ирония. Мне не нужно есть. Я никогда не познаю ГОЛОД. Я не знаю, что чувствуют жертвы голода. И я не могу решить, благословение это или проклятие» (Dini and Ross n.p.).

С этой точки зрения, самая фундаментальная проблема человеческого бытия не имеет «практически никакого значения для Кал-Эла, чья клеточная структура позволяет получать питание не от пищи, а от солнечной энергии» (Waid, p. 8). Из-за своей неуязвимости Супермен не может по-настоящему понять человеческую потребность в безопасности, убежище или защите. Такие заботы, влечения и инстинкты фундаментальные для человека - начинают значить все меньше и меньше, если мы учитываем тот факт, что в рамках комиксной мифологии Супермен был показан как способный выдержать прямой термоядерный взрыв, пролететь сквозь черные дыры и сделать алмазы из угля голыми руками. Здесь соображения Мура становятся важными, учитывая то, что, хотя боль может быть в теле, то страдание - в разуме. Супермен поднимает онто-экзистенциальный и психологический вопрос о том, действительно ли тело, которое не чувствует боли в большинстве обстоятельств, но испытывает наиболее выраженные виды боли как психологические феномены, вообще понимает страдание.

Если онтологические и экзистенциальные переживания персонажа не могут быть сведены к человеческим физиологическим потребностям, влечениям или инстинктам, то путем исключения можно предположить, что потребность Супермена в принадлежности является истинной первичной мотивацией его действий и определяет прочность психосоциальных, культурных и идеологических связей персонажа (и желание их поддерживать) с человеческим существом. Казалось бы, такое предположение совершенно логично, ведь иначе зачем Супермену быть Кларком Кентом, человеком, который работает, живет городской жизнью, наблюдает и подчиняется социально-политическим, экономическим и идеологическим структурам принципиально отличного и во многом меньшего типа бытия, чем его собственный? Почему персонаж не решает покинуть Землю или любое диегетическое 
представление планеты с ее обитателями, начав исследовать необъятные просторы космоса, насколько хватит его интереса и пока излучение желтых звезд остается для него доступным? Можно предположить, что Кал-Эл соединяется с миром парадоксальным образом, то есть, используя свое инопланетное наследие для интеграции в человечество.

Этот общепринятый взгляд, поддерживаемый теми, кто процитирован выше, и многими другими, выдает романтическую слепоту: изза своей силы, необычного, человекоподобного тела и Инаковости; Супермен является, как онто-экзистенциально, так и психологически, неизбежно парадоксальным персонажем. Такое романтическое прочтение Супермена отрицает то, что я считаю одним из самых любопытных его аспектов, а именно трагическое и замкнутое существование в реальности, которую он в силах изменить, но психологически запрещает себе изменять. Вместо этого сила персонажа расходуется на увековечивание условий его собственных страданий и его неспособности действовать решительно, чтобы справиться с травмой и трагедией, связанными не только с тем, что он является могущественным и сверхъестественным Чужим, но и с тем, что в конечном итоге означает бытие на диегетической Земле, где есть такое существо, как Супермен.

Экстремальный подтекст здесь заключается в том, что Супермен не способен спасти мир из-за собственной потребности принадлежать к миру, каким он его видит, - со всеми апориями, проблемами и жаждой большего, лучшего, альтернативы, перемен, власти. Удовольствие, которое персонаж получает от этого, перевешивает желание героя решительно изменить его. Полагаю, что отказ Супермена от активного и неустанного изменения мира может быть истолкован только как выбор, который он делает сам и который он берет на себя. Это выбор с моральными и экзистенциальными последствиями, которые напоминают мысль Тхить Нят Ханя о том, что людям трудно отказаться от страданий, они ищут знакомые страдания или саму привычность страданий из-за страха перед неизвестным. Для Супермена это - страх перед неизвестностью радикальной изоляции, который, в свою очередь, питает потребность персонажа в принадлежности и ее самые неблагоприятные последствия не только для него самого, но и для людей, населяющих Мультивселенную DC. 


\section{IV. ВО ИМЯ УДОВОЛЬСТВИЯ СВЕРХСУЩЕСТВА: НАСЛАЖДЕНИЕ, БОЛЬ И СТРАДАНИЕ В «СУПЕРМЕНЕ»}

Что здесь ставится на карту, так это последствия удовольствия, получаемого персонажем от того, что он является Суперменом, и предположение Уэйда о том, что Супермен удовлетворяет свою потребность в принадлежности именно тем, что он - Супермен. Вывод, который следует сделать из предложенного Уэйдом, заключается в том, что Супермен не может решительно вмешиваться в изменение мира из-за потребности или желания персонажа принадлежать. Его нужды или желания конкретной самости, субъектности и идентичности неразрывно связаны не только с существованием основных человеческих мучений и страданий, но и с их сохранением и продлением. Если смотреть с этой точки зрения, то страдания, необходимые Супермену для осуществления его мечты о принадлежности, и человеческая потребность в облегчении страданий, удовлетворяемая тем, что Супермен пристрастный реактивный агент морального и этического карательного «правосудия», а также идеологического и репрессивного действия, проблематичны, если этот персонаж оценивается как герой. Это связано с тем, что в конечном итоге потребность героя принадлежать и удовольствие, которое он получает от этого, по сути, является галлюцинацией, наваждением, основанным на страданиях тех, кому он «помогает» и усугубляет их, служа самому себе.

Эта тавтологическая и психологически парадоксальная логика в отношениях Супермена к страданию ставит под сомнение гуманистический статус персонажа. Несмотря на бесчисленные и колоссальные силы персонажа и заложенный в них потенциал, несмотря на его благородные намерения и идеалистические фантазии о так называемом человеческом инстинкте «добра», и Супермен, и диегетические люди, которых он спасает, поступают таким образом, что закрепляют необходимость в спасителе: Супермен страдает от человечества, а человечество страдает от Супермена. Вопреки общепринятой трактовке иерархии потребностей персонажа, я утверждаю, что такова правда о Супермене и о нас самих. Вот что скрывается под лазурью, багрянцем и золотом яркой ливреи и столь же яркого образа силы, стабильности и альтруизма, который демонстрирует герой. Это постоянная, неясная и темная правда земного диегетического опыта Супермена.

Моя оценка страданий персонажа - своеобразной основы одержимости / желания принадлежать - как самоподдерживающихся и, в конечном счете, идеологически репрессивных и неэтичных, сводится в психоаналитических терминах к восприятию Супермена не как бога, 
а как невротика. Важно отметить, как это делает Карл Юнг в книге «Слово и образ» (1979), что невроз носит заместительный характер, то есть «невроз всегда является заменой закономерного страдания» (Jung, p. 123). Таким образом, психоэмоциональные страдания, которые испытывает Супермен в результате окончательного тупикового положения между своей Инаковостью и желанием принадлежать к людям и планете, в которых его Инаковость всегда присутствует, независимо от того, насколько хорошо она сублимирована в представлениях человечества, замещают и продлевают страдания тех, кого он стремится, по иронии судьбы, защитить от страданий.

В этом смысле, принадлежность - это человеческое решение инопланетной проблемы, возникающее в результате несоответствия между тем, чем его учат быть, и тем, чем он уже является и становится. Хуже, пожалуй, то, что единственный вывод, который можно сделать из моей критики Уэйда здесь, это, как выразился Фредрик Джеймсон в «Археологии будущего: утопия и иные научные вымыслы» (2007), что «пришелец, полностью ассимилированный, с его Отличием, трансформированным в Идентичность, просто станет капиталистом, как и все мы» (Jameson, p. 141).

Предположение о том, что связь Супермена с Землей и людьми основана на желании принадлежать, соответствует фрейдистской трактовке желания, которая связывает волеизъявление, недостачу и индивидуума в нескольких аспектах. Супермен, согласно приведенной нами выше иерархии желаний персонажа, хочет принадлежать к человеческому роду больше, чем использовать свою силу для изменения бытия в принявшем его мире, потому что ему не хватает собственных истоков, наследия, народа, культуры и языка в живом, общинном, неархивированном и / или статичном смысле. Хотя у Супермена есть референтные копии этих явлений в виде истории Криптона и его народа, записанных и хранящихся на криптонских солнечных камнях - кристаллических структурах, используемых в качестве источников энергии и устройств хранения данных, - в Крепости одиночества жизненный опыт Супермена как криптонца обычно изображается как единичный и радикально изолированный. Постоянное стремление героя к инклюзивности, общности и принадлежности, присущее человеческому бытию, обусловлено отсутствием или недостатком происхождения (Криптона). Таким образом, для Супермена человеческое существо функционирует как протез происхождения. Ссылаясь на «По ту сторону принципа удовольствия» и алголагнию, я теперь кратко остановлюсь на последствиях сущностной потребности Супермена в принадлежности и той 


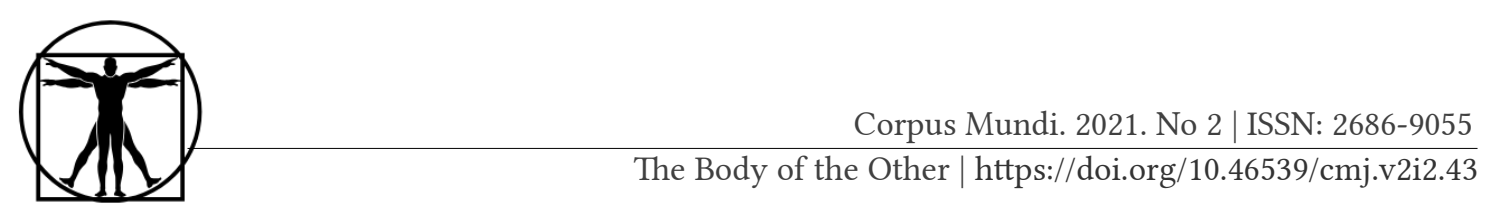

доли удовольствия, которую он извлекает из этого, с точки зрения фрейдизма.

Фрейд определяет принцип удовольствия следующим образом: «Любой данный процесс берет начало в неприятном состоянии напряжения и направляется туда, где его конечная цель будет совпадать с ослаблением этого напряжения, то есть с избеганием «боли» или с получением удовольствия» (Freud, 1922, p. 6). В этой конструкции заложена диалектическая оппозиция между стабильностью и нестабильностью: движение к удовольствию можно рассматривать как движение к стабильности до определенного предела. Боль, напротив, отходит от этого движения по направлению к наслаждению равновесием. Фрейдовское определение принципа удовольствия, как и определение бытия Артуром Шопенгауэром в работе «Мир как воля и представление» (1859), предполагает, что человеческое существование по сути своей негативно. С этой пессимистической точки зрения, мотивацией поступков человека всегда является облегчение травмы бытия. Это облегчение всегда воображаемое или, по крайней мере, метафорическое, в той же мере, в какой оно временное. Оно воображаемо в силу различных проблем, связанных с претензией языка на чистую репрезентацию, примером которой является произвольность семиологического знака. В конце концов, именно через символы и язык человек впервые осознает свое положение и пытается действовать в ответ на него. Это временное явление в том смысле, что желание смягчить травмы бытия никогда не может быть полностью отменено. Боль, страдания, физические, психологические, эмоциональные и так далее возвращаются подобно голоду, который преследует человека на протяжении всей жизни. Поэтому понятия удовольствия и боли сами по себе не относятся к какому-либо чистому опыту. Например, алголагния черпает удовольствие именно из боли, причем, как правило, боль сосредоточена в традиционно признанном месте удовольствия, то есть в эрогенной зоне.

По Фрейду, принцип удовольствия сталкивается с доминированием инстинкта самосохранения, который в конечном итоге вытесняет принцип удовольствия, заменяя его тем, что Фрейд называет принципом реальности (Freud, p. 6). Принцип реальности не полностью отделен от движения к максимизации удовольствия и движения к стабильности и равновесию, но он сублимирует его таким образом, чтобы отличаться от достижения удовольствия. Стало быть, принцип реальности «требует и заставляет откладывать удовлетворение, отказываться от разнообразных возможностей его получения и временно терпеть «боль» на долгом и извилистом пути к удоволь- 
ствию» (Freud, p. 6). Принцип реальности, как таковой, способствует разрушению изначальной диалектики удовольствия и боли, когда каждое явление способно порождать другое, содержать, отражать и вызывать необходимость другого. К примеру, кто-то может получать удовлетворение от использования своей власти для принуждения другого к подчинению его собственной воле. Это желание, противоречит предопределенным законам, морали, этике и хорошим нормам поведения, через которые субъект должен существовать и выражать себя, и в то же время синтезировано и интернализовано для усмирения таких разрушительных, сильных, мощных желаний. Результатом этого является их подавление идеологически обусловленными кодами нормального, хорошего или приемлемого поведения. Желание, которое само по себе также является формой власти, отсекается, вытесняется из возможности своей актуализации. Если, однако, подавленное желание пробивается «окольными путями к прямому или замещающему удовлетворению, то этот успех, который в противном случае мог бы принести удовольствие, переживается [субъектом] как «боль»» (Freud, p. 7). Боль от достижения удовольствия сосредоточена в расщеплении, предательстве. Субъект испытывает боль от актуализации желания, которое нарушает санкционированный способ бытия и, таким образом, является удовольствием, которое не разрешено диктатом языка, морали, этики и так далее, чтобы оказаться пережитым как таковое - как удовольствие. Боль, таким образом, - это удовольствие, которое не может быть пережито как удовольствие.

Что означает фрейдистский экскурс в психоэмоциональную алголагнию для существа, чье существование и сама сила этого существования нарушают и задерживают почти до бесконечности человеческие процессы боли, удовольствия, восприятия и предвкушения того и другого, как в случае с представлением об опасности? Другими словами, как функционируют удовольствие, боль, желание и все порождаемые ими страдания, если они вообще существуют, в Супермене? Что поставлено на карту в миметическом присвоении персонажем этих человеческих феноменов и процессов их восприятия, интерпретации и реагирования? Что означает шопенгауэровское, то есть пессимистическое, мировоззрение, лежащее в основе человеческого бытия, для сверхсущества, которое, с одной стороны, не испытывает страха или голода, но, с другой стороны, по словам Уэйда, страдает в силу крайнего чувства одиночества? Если, перефразируя Карла Маркса, единственным противоядием от душевных страданий является физическая боль, а сверхчеловек не может чувствовать физическую боль так же, как люди, то каким может быть противоядие от его острых психоэмоциональных стра- 


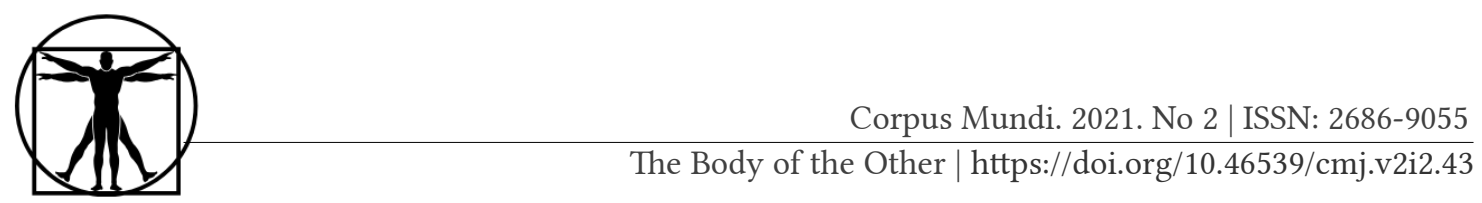

даний? В заключение я бы предположил, что выдвинутая мной концепция, а именно Супермен-как-алголагник, является индикатором более широкой проблемы, а именно: то, что дает Супермену толику удовольствия, иллюзорного, отсроченного, отдаленного и временного, является одновременно источником боли и закономерностью его существования.

Таким образом, активный поиск чувства принадлежности, акт бытия Супермена и ситуация с его силой на диегетической Земле неизменно увековечивает не только страдания самого персонажа, но и страдания миллиардов людей из мультивселенной DC, которые с радостью, облегчением, удивлением и преклонением взирают на пришествие Супермена. Это самая мрачная ирония Супермена. Если он получает удовольствие от того, что является Суперменом и помогает другим, как утверждает Уэйд, то это удовольствие неотделимо от боли, несчастья, страдания и страха тех, кого он спасает: его инопланетное удовольствие, таким образом, неотделимо от человеческой боли.

\section{V. ЗАКЛЮЧЕНИЕ: БЕСПРОСВЕТНАЯ БОЛЬ}

Важно помнить, что в рамках исторически последовательной истории происхождения персонажа, Супермен не послан на диегетическую Землю с какой-либо целью или миссией. Он отправлен в космос в первую очередь ради выживания. Поэтому диегетические люди, с которыми он сталкивается, не заставляли его быть или, что более важно, оставаться Суперменом. Он решил принять свою самоопределяющуюся идеологическую, моральную и этическую миссию, а также использовать свою силу исключительно на службе этой миссии, решительно согласовав свою силу с этим земным телосом, страдая от него, перенося и принимая его на себя. В результате, нет опыта удовольствия без одновременного опыта боли для Супермена. Боль, порожденная удовольствием от служения человечеству, провоцирует экзистенциальное кризисное состояние, в котором ощущение счастья, удовольствия, принадлежности или идентичности Супермена обусловлено постоянными страданиями тех, кому он служит, равно как и его собственные страдания порождаются и увековечиваются вытеснением, присущим его сверхъестественному состоянию, его силе и Инаковости. Они вмещают и порождают друг друга.

Таким образом, Супермен - это алголагник, чья патологически невротическая потребность в принадлежности ставит под сомнение статус героя как образца альтруистического действия. При переоценке мифологии этого персонажа, а в дальнейшем и любого комиксового 
сверхсущества, обладающего столь же радикальными способностями и Инаковостью, необходимо задать вопрос, в самом ли деле Супермен занимается спасением мира, его сохранением или же его заботит увековечивание и поддержание своего упадка ради собственного удовольствия. Если цель желания Супермена - это действительно спасти или изменить мир, как часто заявляет герой, то достижение этого желания, по крайней мере, психологически, всегда откладывается из-за его потребности в принадлежности. В последнем случае психоаналитический ракурс показывает, что даже сверхсущества попадают в сети человеческих неврозов на диегетических Землях и страдают от них, и, по сути, усугубляют их своей деятельностью в качестве супергероев. В последнем случае утопический потенциал блистательного Завтра, заложенный в силе и Инаковости персонажа, перечеркивается его психологической потребностью принадлежать страданиям нескончаемой битвы Сегодня.

\section{Список литературы}

Coogan, P. M. \& O'Neil D. (2006). Superhero: The Secret Origin of a Genre. Austin, TX: MonkeyBrain Books.

Fingeroth, D. (2004). Superman On The Couch: What Superheroes Really Tell Us About Ourselves and Our Society. New York: Continuum.

Freud, S. \& Hubback, C. J. M. (1922). Beyond the Pleasure Principle. London: The International psycho-analytical Press.

Freud, S. (1919). Totem and Taboo: Resemblances Between the Psychic Lives of Savages and Neurotics. Routledge.

Jameson, F. (2005). Archaeologies of the Future: The Desire Called Utopia and Other Science Fiction. New York: Verso.

Jung, C. G. (1979). Word and Image. New York: Princeton University Press.

Lawrence, J. (2006). You Will Believe: The Cinematic Saga of Superman. Warner Brothers Pictures.

Loeb, J, \& Morris, T. (2005). Heroes and Superheroes. In T. Morris, M. Morris and W. Irwin (Eds.) Superheroes and Philosophy: Truth, Fustice, and the Socratic Way (pp. 11-21). U.S.: Open Court Publishing Co.

Moore, A. and Gibbons, D. (1985). Superman Annual Vol.1, No. 11. New York: DC Comics.

Reynolds, R. (1994). Super Heroes: A Modern Mythology. Jackson: University Press of Mississippi.

Ross, A. \& Dini, P. (1999). Superman: Peace on Earth. New York: DC Comics.

Waid, M. (2005) "The Real Truth about Superman: And the Rest of Us Too. In T. Morris, M. Morris and W. Irwin (Eds.) Superheroes and Philosophy: Truth, Fustice, and the Socratic Way (pp. 3-11). U.S.: Open Court Publishing Co.

Weldon, G. (2013). Superman: The Unauthorized Biography. Hoboken, N.J.: Wiley. 


\section{References}

Coogan, P. M. \& O'Neil D. (2006). Superhero: The Secret Origin of a Genre. Austin, TX: MonkeyBrain Books.

Fingeroth, D. (2004). Superman On The Couch: What Superheroes Really Tell Us About Ourselves and Our Society. New York: Continuum.

Freud, S. \& Hubback, C. J. M. (1922). Beyond the Pleasure Principle. London: The International psycho-analytical Press.

Freud, S. (1919). Totem and Taboo: Resemblances Between the Psychic Lives of Savages and Neurotics. Routledge.

Jameson, F. (2005). Archaeologies of the Future: The Desire Called Utopia and Other Science Fiction. New York: Verso.

Jung, C. G. (1979). Word and Image. New York: Princeton University Press.

Lawrence, J. (2006). You Will Believe: The Cinematic Saga of Superman. Warner Brothers Pictures.

Loeb, J, \& Morris, T. (2005). Heroes and Superheroes. In T. Morris, M. Morris and W. Irwin (Eds.) Superheroes and Philosophy: Truth, Fustice, and the Socratic Way (pp. 11-21). U.S.: Open Court Publishing Co.

Moore, A. and Gibbons, D. (1985). Superman Annual Vol.1, No. 11. New York: DC Comics.

Reynolds, R. (1994). Super Heroes: A Modern Mythology. Jackson: University Press of Mississippi.

Ross, A. \& Dini, P. (1999). Superman: Peace on Earth. New York: DC Comics.

Waid, M. (2005) "The Real Truth about Superman: And the Rest of Us Too. In T. Morris, M. Morris and W. Irwin (Eds.) Superheroes and Philosophy: Truth, Fustice, and the Socratic Way (pp. 3-11). U.S.: Open Court Publishing Co.

Weldon, G. (2013). Superman: The Unauthorized Biography. Hoboken, N.J.: Wiley. 